\title{
$\underset{\text { ACCESS }}{\text { OPEN }}$ BY
}

\section{Endoparasitic helminths in Baltic salmon Salmo salar: ecological implications}

\author{
Agung Cahyo Setyawan, Shaozhi Zuo, Per W. Kania, Kurt Buchmann* \\ Department of Veterinary and Animal Science, Faculty of Health and Medical Sciences, University of Copenhagen, \\ Frederiksberg C 1870, Denmark
}

\begin{abstract}
Parasites in fish are ecological indicators, as they reflect the host's migration routes, feeding behavior and immune status. We performed a parasitological investigation of sea-running Baltic salmon to study the use of parasites as indicators for this fish stock. The host - a strain of Atlantic salmon Salmo salar - has been isolated for several millennia in the semi-enclosed brackish Baltic Sea, with limited migration to and from the North Sea. Twenty-four salmon (total body weight: $4.2-14.2 \mathrm{~kg}$; total body length: $80-105 \mathrm{~cm}$ ) were caught by spoon bait in the southern Baltic Sea during feeding migrations, necropsied shortly afterwards and internal organs subjected to parasitological investigation focusing on endoparasitic helminths. The pyloric region was heavily parasitized by the cestode Eubothrium crassum (100\% prevalence; intensity: 97-273 parasites per infected fish), reflecting a diet of smaller pelagic fishes. The stomach contained the hemiurid digeneans Brachyphallus crenatus (95.8\% prevalence; intensity: 8-151) and Hemiurus luehei (58.3\% prevalence; intensity: 2-13), indicating a diet of clupeids. Schistocephalus solidus (25\% prevalence; intensity: 1-2), liberated from ingested sticklebacks, the acanthocephalan Echinorhynchus truttae (54\% prevalence; intensity: 1-13) and the adult nematode Hysterothylacium aduncum (29\% prevalence; intensity: 1-13) were found in the intestine. The liver was parasitized by third-stage nematode larvae of Contracaecum osculatum (45.8\% prevalence; intensity: 1-4), but these were growth-stunted and encapsulated. The parasite fauna differs markedly from salmon in North Atlantic waters, and the lack of purely marine parasite species indicates that the Baltic salmon has remained in the Baltic Sea during its life history.
\end{abstract}

KEY WORDS: Baltic Sea $\cdot$ Salmon $\cdot$ Parasites $\cdot$ Helminths $\cdot$ Ecoparasitology $\cdot$ Life cycle

\section{INTRODUCTION}

Baltic salmon is a sub-stock of Salmo salar populating the Baltic Sea, the semi-enclosed brackish water system located between the coastlines of Denmark, Sweden, Finland, Russia, the Baltic republics (Estonia, Latvia, Lithuania), Poland and Germany. Salmon-running rivers supplying fish to the Baltic are found in all these countries except Denmark, and smolts migrate from their home river to the Baltic feeding grounds, returning to their spawning sites after 1-4 yr (Karlsson \& Karlström 1994). Hydrographic conditions in the Baltic Sea are characterized

${ }^{*}$ Corresponding author: kub@sund.ku.dk by a marked shift in salinity from almost freshwater in the northern Bothnian Bay to $>30$ ppt in the western Baltic, where high-salinity North Sea waters enter through the Danish straits (Herlemann et al. 2011). These brackish conditions lead to low biodiversity and thus less diverse food sources for the salmon. Research on this salmon stock has mainly focused on reproduction, chemical pollution, fishing mortality and feeding biology (Larsson 1984, Karlsson \& Karlström 1994, Karlsson et al. 1999, Berglund et al. 2001, Hansson et al. 2001). Except for a few specific investigations on the digenean fauna in Polish salmonids by Slusarski (1958), Bothnian salmon (Val-

() The authors 2019. Open Access under Creative Commons by Attribution Licence. Use, distribution and reproduction are unrestricted. Authors and original publication must be credited. 
tonen et al. 1984) and nematodes in Finnish salmon (Fagerholm 1982), disease investigations have concentrated on salmon fry, parr and smolt in freshwater habitats (lakes, hatcheries, farms, rivers) and the health of returning spawners (Karlsson \& Karlström 1994). A traditional salmon fishery conducted by Danish fishermen around the island Bornholm in the southern Baltic Sea has been present for centuries, but no detailed and broadly covered description of parasite infections in these salmonids is available. Data from other marine areas suggest that basic biological information concerning feeding and immune status can be extracted by analyzing the presence of certain parasite species in a fish population, e.g. in salmon from the White Sea (Dogiel \& Petruschevski 1934), Canada (Hicks \& Threlfall 1973) and the Pacific (Margolis 1965). In addition, salmon acquire specific parasites in certain habitats, which subsequently can be applied to indicate migration of stocks; this application has been termed parasitological tagging (Kabata 1963, Beverley-Burton \& Pippy 1978, Pippy 1980, Williams et al. 1992, MacKenzie 2002, Timi 2003). We performed a study on endoparasitic helminths of Baltic salmon caught during their feeding migration in the southern Baltic Sea, and we present biological information on feeding and migration routes extracted from the parasite fauna recorded.

\section{MATERIALS AND METHODS}

\subsection{Fish}

A total of 24 specimens of sea-running Baltic salmon were examined. They were caught by anglers on small fishing vessels using spoon baits on April 27, 2017 in the southern Baltic Sea 3-10 nautical miles $(5.5-18.5 \mathrm{~km})$ from the coastline of the island Bornholm $\left(55.8^{\circ} \mathrm{N}, 14.5^{\circ} \mathrm{E}\right)$. The salmon were recovered from the fishermen after landing $(2-4 \mathrm{~h}$ after catch) in the fishing village Tejn (northeastern part of Bornholm) during the Trolling Master Bornholm Competition (April 26-29, 2017). The 24 salmon (17 females, 7 males) had reached a total body weight ranging from 4.2 to $14.2 \mathrm{~kg}$ (mean \pm SD for all: $9.3 \pm$ $2.7 \mathrm{~kg}$; females: $9.4 \pm 3.0 \mathrm{~kg}$; males: $9.2 \pm 3.0 \mathrm{~kg}$ ), and total body length from 80 to $110 \mathrm{~cm}$ (mean \pm SD for all: $93.25 \pm 8.3 \mathrm{~cm}$; females: $93.5 \pm 8.9 \mathrm{~cm}$; males: 91.9 $\pm 6.5 \mathrm{~cm}$ ). They were necropsied shortly after landing, and the esophagus, stomach, pyloric caeca, intestine, spleen and liver from each fish were recovered and frozen in plastic bags at $-20^{\circ} \mathrm{C}$.

\subsection{Parasite collection}

The frozen material was transported to the laboratory at the University of Copenhagen, and following thawing, salmon entrails were examined for the presence of helminths as described by Buchmann (2007). In brief, organs were placed in separate Petri dishes in physiological saline. The esophagus, stomach, pyloric region and intestine were opened by longitudinal sections. Stomach contents were recorded to obtain information about feed intake in the area. Mucosal surfaces of the stomach and intestine were scraped into Petri dishes with physiological saline with a scalpel and scrutinized under a dissection microscope (magnification: 7-40x), and helminths were isolated by forceps or pipettes. The liver and spleen were sectioned into smaller parts and examined for the presence of helminths by the compression technique between two $10 \mathrm{~mm}$ glass plates $(15 \times$ $15 \mathrm{~cm}$ ) (Buchmann 2007). Helminths isolated from the salmon organs were then rinsed in physiological saline and transferred to $70 \%$ ethanol for further morphological and molecular identification.

\subsection{Morphological identification}

Standard staining was performed (hematoxylin, Harris' modified solution, Sigma-Aldrich HHS32) on subsamples from each helminth group, and specimens were mounted on microscope slides in Aquatex mounting medium (Merck). Morphological identification of parasites was performed for digeneans following Køie (1984), cestodes by Chubb et al. (1987) and Scholz et al. (2003), acanthocephalans by Brown et al. (1986) and nematodes following Fagerholm (1982).

\subsection{Molecular confirmation}

Species identification of helminths was confirmed by molecular methods (PCR and sequencing). A part of each individual parasite (10 parasite specimens per species) was taken for molecular analysis using lysis, DNA purification, PCR with specific primers (Table 1), product purification, sequencing and BLAST analysis. The lysate was prepared with a QIAGEN ${ }^{\circledR}$ DNeasy Blood \& Tissue Kit, and PCR performed in $60 \mu \mathrm{l}$ PCR mix which contained $2 \mu \mathrm{l}$ sample, $6 \mu$ forward primer $(10 \mathrm{mM}), 6 \mu$ reverse primer (10 mM), $6 \mu \mathrm{l} 10 \times$ PCR buffer, $6 \mu \mathrm{l}$ dNTP $(4 \times 10 \mathrm{mM})$, $1.8 \mu \mathrm{MgCl}_{2}$ (50 mM), $0.25 \mathrm{U}$ DNA polymerase (Bioline) and $\mathrm{H}_{2} \mathrm{O}$ (Zuo et al. 2018). The PCR outline was 
Table 1. List of primers

\begin{tabular}{|c|c|c|c|}
\hline Parasite & Primer name & Sequence $\left(5^{\prime}-3^{\prime}\right)$ & Reference \\
\hline Acanthocephala & $\begin{array}{l}\text { Acanth_F1 } \\
\text { Acanth_R1 }\end{array}$ & $\begin{array}{l}\text { AGA TTA AGC CAT GCA TGC GTA AG } \\
\text { TGA TCC TTC TGC AGG TTC ACC TAC }\end{array}$ & Verweyen et al. (2011) \\
\hline Cestoda: Schistocephalus & $\begin{array}{l}\text { CYTW3F2 } \\
\text { CYTW3R5 }\end{array}$ & $\begin{array}{l}\text { CTA ATT GGT GTG TGA TCT GGT TTT G } \\
\text { GGA GTG GGA GCC CAA CAC AAG }\end{array}$ & Sprehn et al. (2014) \\
\hline Cestoda: Eubothrium & $\begin{array}{l}\mathrm{BD} 1 \\
\mathrm{BD} 2\end{array}$ & $\begin{array}{l}\text { GTC GTA ACA AGG TTT CCG TA } \\
\text { TAT GCT TAA ATT CAG CGG GT }\end{array}$ & Kralova et al. (2001) \\
\hline Nematoda & $\begin{array}{l}\mathrm{NC} 2 \\
\mathrm{NC} 5\end{array}$ & $\begin{array}{l}\text { TTA GTT TCT TTT CCT CCG CT } \\
\text { GTA GGT GAA CCT GCG GAA GGA TCA }\end{array}$ & Zhu et al. (2007) \\
\hline Trematoda & $\begin{array}{l}\text { Erib1 } \\
\text { Erib10 }\end{array}$ & $\begin{array}{l}\text { ACC TGG TTG ATC CTG CCA G } \\
\text { CTT CCG CAG GTT CAC CTA CGG }\end{array}$ & Barta et al. (1997) \\
\hline
\end{tabular}

pre-denaturation at $95^{\circ} \mathrm{C}$ for $5 \mathrm{~min}$; amplification by a number of cycles starting with denaturation at $95^{\circ} \mathrm{C}$ for $30 \mathrm{~s}$, followed by annealing at an assay-specific temperature for $30 \mathrm{~s}$, and ending with elongation at $72^{\circ} \mathrm{C}$; and finally a post-elongation step at $72^{\circ} \mathrm{C}$ for $7 \mathrm{~min}$. In order to increase the specificity of some of the PCR procedures, touchdown procedures were applied by using a gradient of annealing temperatures starting $7^{\circ} \mathrm{C}$ above the final one. The regime of annealing temperatures of a touchdown from 57 to $50^{\circ} \mathrm{C}$ was 2 cycles at $57^{\circ} \mathrm{C}, 2$ cycles at $55^{\circ} \mathrm{C}, 2$ cycles at $54^{\circ} \mathrm{C}, 3$ cycles at $53^{\circ} \mathrm{C}, 3$ cycles at $51^{\circ} \mathrm{C}, 3$ cycles at $51^{\circ} \mathrm{C}$ followed by 30 cycles at $50^{\circ} \mathrm{C}$. For cestodes and acanthocephalans, the touchdown procedure was applied in an annealing temperature range between 59 and $52^{\circ} \mathrm{C}$, and for trematodes from 57 to $50^{\circ} \mathrm{C}$ (elongation time of $90 \mathrm{~s}$ ). For nematodes, the annealing temperature and elongation time were $53^{\circ} \mathrm{C}$ and $90 \mathrm{~s}$, respectively. All PCR products were analyzed by agarose gel electrophoresis in ethidium bromidestained $1.5 \%$ agarose gels and subsequently purified using the illustra ${ }^{\mathrm{TM}}$ GFX ${ }^{\mathrm{TM}}$ PCR DNA purification kit (GE Healthcare) and sequenced (Macrogen Korea). Sequences were analyzed using the software CLC Main Workbench v.7.9.1 (Qiagen) and confirmed by BLAST ${ }^{\circledR}$ analysis in GenBank.

\subsection{Statistics}

The infection level of salmon for each parasite species was calculated as prevalence (percentage of hosts infected), mean intensity (mean number of parasites per infected fish), range (lowest and highest number of a particular species recorded in a host) and abundance (number of parasites per fish including both infected and non-infected fish) according to
Bush et al. (1997). The correlation between the host weight and the number of parasites for each parasite species was calculated by the Spearman rank correlation test in order to elucidate any size-dependent infection. Any interspecific interaction between different parasite species in the intestine was investigated by a chi-squared test. For all tests performed, a significance level of 0.05 was applied. All calculations were performed in GraphPad Prism v.7.2.

\section{RESULTS}

The fish were heavily parasitized (pyloric caecum location) by adult cestodes Eubothrium crassum, whereas another cestode species, Schistocephalus solidus (intestinal location), occurred less frequently. Adult trematodes Brachyphallus crenatus and Hemiurus luehei (stomach location) were prevalent. The acanthocephalan Echinorhynchus truttae (adults in the intestine) and adult nematodes of the species Hysterothylacium aduncum (intestine) occurred sporadically, whereas third-stage nematode larvae Contracaecum osculatum were found in livers more frequently (Table 2). Significant positive correlations between host body weight and infection intensity were found for the adult stomach digeneans (Table 3). Of all collected parasite specimens (a total of 5179), the cestode Eubothrium crassum in the pyloric caeca dominated $(79.9 \%$ of all parasites), the hemiurid trematode $B$. crenatus in the stomach was the second most frequent (16.5\% of all), the trematode Hemiurus luehei accounted for $1.4 \%$, while the remaining parasites, including intestinal acanthocephalans $(1.3 \%)$, intestinal nematodes $(0.4 \%)$, liver nematodes $(0.4 \%)$ and the schistocephalid cestodes $(0.1 \%)$ in the intestine, were relatively infrequent. Co-occur- 
Table 2. Prevalence (percentage of hosts infected), mean intensity (mean number of parasites per infected fish), range (lowest and highest number of a particular species recorded in a host), abundance (number of parasites per fish including both infected and non-infected fish) and molecular confirmation of endohelminths in Baltic salmon Salmo salar (n = 24). ITS: internal transcribed spacer

\begin{tabular}{|lccccccc|}
\hline Parasite & $\begin{array}{c}\text { No. of } \\
\text { infected fish }\end{array}$ & $\begin{array}{c}\text { Prevalence } \\
(\%)\end{array}$ & $\begin{array}{c}\text { No. of } \\
\text { parasites }\end{array}$ & $\begin{array}{c}\text { Intensity } \\
\text { Mean }\end{array}$ & Range & Abundance & $\begin{array}{c}\text { GenBank accession } \\
\text { no. (genetic region) }\end{array}$ \\
\hline Eubothrium crassum & 24 & 100 & 4142 & 172.6 & $97-273$ & 172.6 & AF229028 (ITS) \\
Schistocephalus solidus & 6 & 25 & 6 & 1 & $1-2$ & 0.3 & AP017669 (COX1) \\
Brachyphallus crenatus & 23 & 95.8 & 853 & 37.1 & $8-151$ & 35.5 & KM401883 (18S) \\
Hemiurus luehei & 14 & 58.3 & 72 & 5.2 & $2-13$ & 3 & KM401883 (18S) \\
Hysterothylacium aduncum & 7 & 29.2 & 21 & 3 & $1-13$ & 0.8 & AB277826 (ITS) \\
Contracaecum osculatum & 11 & 45.8 & 20 & 1.8 & $1-4$ & 0.8 & KM273050 (ITS) \\
Echinorhynchus truttae & 13 & 54.2 & 65 & 5 & $1-13$ & 2.7 & AY218123 (ITS) \\
\hline
\end{tabular}

Table 3. Spearman rank correlation between Salmo salar host size (weight) and number of parasites. Significant correlations in bold

\begin{tabular}{|llrl|}
\hline $\begin{array}{l}\text { Parasite } \\
\text { group }\end{array}$ & Species & $\begin{array}{c}\text { Correlation } \\
\text { coefficient }\end{array}$ & $\mathrm{p}$ \\
\hline Cestodes & Eubothrium crassum & 0.25 & $>0.05$ \\
& Schistocephalus solidus & -0.45 & $>0.05$ \\
Trematodes & Brachyphallus crenatus & $\mathbf{0 . 4 0}$ & $<\mathbf{0 . 0 5}$ \\
& Hemiurus luehei & $\mathbf{0 . 4 5}$ & $<\mathbf{0 . 0 5}$ \\
Nematodes & Hysterothylacium aduncum & 0.50 & $>0.05$ \\
& Contracaecum osculatum & 0.48 & $>0.05$ \\
Acantho- & Echinorhynchus truttae & -0.26 & $>0.05$ \\
cephalans & & & \\
\hline
\end{tabular}

rence of the 3 different parasite species located in the intestine was noted (Table 4). The number of fish with presence of 2 or 3 species together did not differ significantly from the number of fish with only 1 species present. The stomach contents included sticklebacks (1-44 sticklebacks in 14 of the 24 salmon), clupeids (herring, sprat) (1-3 found in 6 of the 24 salmon), garfish (1-4 found in 3 of the 24 salmon), and cod ( 1 found in 3 of the 24 salmon).

Table 4. Occurrence and co-occurrence of endohelminths in Baltic salmon (Salmo salar) intestines. No significant differences, chi-squared test, $\mathrm{p}>0.05$

\begin{tabular}{|c|c|c|}
\hline Parasite species & $\begin{array}{l}\text { No. of species } \\
\text { in } 1 \text { fish }\end{array}$ & $\begin{array}{l}\text { No. of fish with } \\
\text { the infection }\end{array}$ \\
\hline Schistocephalus solidus & 1 & 4 \\
\hline Hysterothylacium aduncum & 1 & 7 \\
\hline Echinorhynchus truttae & 1 & 13 \\
\hline S. solidus $+H$. aduncum & 2 & 1 \\
\hline S. solidus + E. truttae & 2 & 3 \\
\hline H. aduncum + E. truttae & 2 & 6 \\
\hline $\begin{array}{l}\text { S. solidus }+H . \text { aduncum }+ \\
\text { E. truttae }\end{array}$ & 3 & 1 \\
\hline
\end{tabular}

\section{DISCUSSION}

Sea-running Baltic salmon caught in the southern Baltic near the island Bornholm harbor a characteristic parasite fauna which to some extent reflects the special biology of this isolated stock of Atlantic salmon Salmo salar in its brackish environment. The endoparasitic helminths have life cycles involving intermediate hosts, some of which are invertebrates and others are vertebrate species, and it is thereby possible to apply the parasites as a tool to indicate the role of the salmon in the ecosystem (Williams et al. 1992), as the presence and absence of specific parasites provide insight into the ecology of these salmon. Previous investigations on salmon caught in the Atlantic documented that a number of marine parasite species, such as Anisakis simplex, are prevalent (Beverley-Burton \& Pippy 1978, Margolis \& Arthur 1979, Murphy et al. 2010), and it is noteworthy that this was absent in the Baltic salmon. This indicates that Baltic salmon do not leave the Baltic, because the $A$. simplex life cycle is restricted to more marine areas and not completed in the Baltic proper (Grabda 1974, 1976). Migrating North Sea herring (springspawning Rügen herring) entering the Baltic from the North Sea during autumn in order to spawn along the German and Polish coastlines (Grabda 1974, 1976, Mehrdana et al. 2014) are infected with A. simplex, and the nematode can be transferred to local predatory fish, such as cod, feeding on this herring stock. However, the absence of this nematode in the present study indicates that Baltic salmon do not feed on long-range migrating North Sea herring in the western Baltic, and the absence of characteristic marine trematodes such as Lecithaster gibbosus and Derogenes varicus, which are known from salmon in the Atlantic (Dogiel \& Petruschevski 1934), further reflects the local migration of Baltic salmon within 
the Baltic Sea. The euryhaline cestode Eubothrium crassum completes its life cycle in marine, brackish and freshwater habitats and its presence in Baltic salmon provides no information on migration routes. It is a common parasite in salmonids both in the Atlantic (Kennedy 1969, 1978) and the Baltic (Buchmann 1987, Unger \& Palm 2016). The E. crassum life cycle includes copepods as first intermediate hosts, small fish (such as perch and sticklebacks) as transport host and salmonids as the final host carrying sexually mature adults (Rosen 1918, Vik 1963, Saksvik et al. 2001). The high number of sticklebacks and clupeids found in the stomach content analysis in the present study indicates that the ingestion of such fish was the main means through which the salmon acquire those tapeworms. This corroborates with previous food-preference recordings in Baltic salmon (Karlsson et al. 1999). The few cod and garfish present in the diet reflect that salmon feed on available food items when available in the ecosystem, but no specific parasites exclusively associated with these 2 species were isolated from salmon. All salmon investigated showed a large E. crassum load, exceeding data from salmon in marine areas (Kennedy 1978) where intensities below 100 cestodes per fish were recorded. The sampled material did not reveal significant interspecific interactions between parasites, probably because the different species occupied different microhabitats (digeneans in the stomach, nematode and acanthocephalan adults in the intestine, nematode larvae in the liver and cestodes in the pyloric caeca). The presence of the cestode Schistocephalus solidus, which uses copepods as first intermediate hosts, sticklebacks as second intermediate hosts and fish-eating birds as final hosts, reflects that the salmon ingested a high number of sticklebacks (Reimchen 1982), as confirmed by the stomach content analyses. As this parasite has not been found in salmon caught in Atlantic waters (Dogiel \& Petruschevski 1934), the occurrence in Baltic salmon could be interpreted as an indication of the characteristic feeding of large Baltic salmon on shoals of sticklebacks, even in open waters. Infection with the trematode Brachyphallus crenatus is acquired by ingestion of various planktivorous fishes such as clupeids and sticklebacks (Køie 1992), but the geographic area in which clupeids acquire infections is associated with distribution of the first intermediate host, the opisthobranch snail Retusa obtusa. Cercariae released from the snail infect copepods and transform into infective metacercariae. When planktivorous fishes ingest infected copepods, the parasite reaches maturity (stomach location) and salmon may subsequently acquire the parasite by eating these hosts (Køie 1992). The wide distribution of this snail, from the Atlantic to the central Baltic Sea (Køie et al. 2000), explains the B. crenatus infections seen in salmon and other salmonids in both the Atlantic (Dogiel \& Petruschevski 1934) and the Baltic (Slusarski 1958, Valtonen et al. 1984, Buchmann 1989, Unger \& Palm 2016). Another hemiurid trematode, Hemiurus luehei, uses the opisthobranch snail Philine denticulata as first intermediate host, a copepod as second intermediate host and planktivorous fish as the final host, after which it can be accumulated in the stomach of larger piscivorous fish (Køie 1990). The snail is restricted to fully marine areas and the western Baltic (Køie et al. 2000) but is found in western Baltic herring stocks throughout the year (Reimer 1970). This suggests that Baltic salmon feed on local Baltic populations of clupeids performing migrations into the western Baltic Sea where they obtain infection with Hemiurus luehei. Hysterothylacium aduncum is a common parasite in both the Baltic and the Atlantic (Sobecka et al. 2011) and it was found in its adult stage in the intestine of Baltic salmon in the present study. Larvae are obtained by the final host fish by ingestion of invertebrate or piscine transport hosts (Køie 1993), but the broad distribution and low infection means it is a less interesting biological tag (Williams et al. 1992, MacKenzie 2002). The relatively low prevalence and intensity of third-stage nematode larvae of Contracaecum osculatum is noteworthy because the parasite is abundant in sprat and cod in the investigated area (Mehrdana et al. 2014; Zuo et al. 2018). The size of the larva in cod liver may reach $21 \mathrm{~mm}$ (Fagerholm 1982), but larvae in Baltic salmon liver all had stunted growth (body lengths: 6-10 $\mathrm{mm}$ ) and were located in small granulomas, which suggests that the immune reactions in salmon towards C. osculatum larvae are more effective compared to cod. The cod genome lacks the genes encoding the adaptive immune elements MHC II and CD4 (Star \& Jentoft 2012), whereas these immune factors in salmonids are active against parasitic invasion (Olsen et al. 2011, Bahlool et al. 2012), which may explain why $C$. osculatum larvae become inactivated in salmon much more effectively and shortly after invasion. The acanthocephalan Echinorhynchus truttae uses benthic crustaceans, such as amphipods Gammarus spp., as intermediate hosts (Awachie 1966). The infection tended to be inversely related to host size, which reflects that larger salmon to a higher degree switch to a piscine diet and limit feeding on small benthic prey animals when they attain a certain size. Sea trout caught in the same area of the Baltic Sea are infected by numerous Echi- 
norhynchus truttae (Buchmann 1989), which accords with the presence of infected amphipods in the habitat. Sea trout from the western Baltic Sea (Unger \& Palm 2016) showed no infection by Echinorhynchus truttae, but had a low infection with Echinorhynchus gadi and Pomphorhynchus laevis, 2 species which were not found in the present work. The 2 investigated habitats differ with regard to salinity and species composition, which may explain the differing parasite communities.

\section{CONCLUSIONS}

The characteristic parasite fauna recorded in Baltic salmon caught during their migration around the island Bornholm in the southern Baltic Sea indicated their food special preferences and their restricted migrations within the Baltic Sea, separating them from salmon in the Atlantic Ocean.

Acknowledgements. The Indonesia Endowment Fund for Education (LPDP) is acknowledged for PhD stipend support to A.C.S. (contract PRJ-88/LPDP.3/2016). The study was supported by the J. P. A. Espersen and Mrs. Dagny Espersen Foundation. We are indebted to staff members who assisted with sampling in the field. Thanks go to Sandra Jeberg, Foojan Mehrdana, Rzgar M. Jaafar, Moonika H. Marana, Jakob Skov, Sanaz Mazaheri, Asma M. Karami, Louise von G. Jørgensen, Cao Lu, Khairul Syahputra and Rozalia Korbut.

\section{LITERATURE CITED}

Awachie JBE (1966) The development and life history of Echinorhynchus truttae Schrank, 1788 (Acanthocephala). J Helminthol 40:11-32

Bahlool QZM, Skovgaard A, Kania P, Haarder S, Buchmann K (2012) Microhabitat preference of Anisakis simplex in three salmonid species: immunological implications. Vet Parasitol 190:489-495

Barta JR, Martin DS, Liberator PA, Dashkevicz M (1997) Phylogenetic relationships among eight Eimeria species infecting domestic fowl inferred using complete small subunit ribosomal DNA sequences. J Parasitol 83: 262-271

Berglund O, Larsson P, Broman D (2001) Organochlorine accumulation and stable isotope ratios in an Atlantic salmon (Salmo salar) population from the Baltic Sea. Sci Total Environ 281:141-151

Beverley-Burton M, Pippy JHC (1978) Distribution, prevalence and mean numbers of larval Anisakis simplex (Nematoda: Ascaridoidea) in Atlantic salmon, Salmo salar L., and their use as biological indicators of host stocks. Environ Biol Fishes 3:211-222

Brown AF, Chubb JC, Veltkamp CJ (1986) A key to the species of Acanthocephala parasitic in British freshwater fishes. J Fish Biol 28:327-334
Buchmann K (1987) Cestodes of migratory trout (Salmo trutta L.) from the Baltic Sea. Bull Eur Assoc Fish Pathol $7: 115-117$

Buchmann K (1989) Trematodes and acanthocephalans of Salmo trutta from the Baltic sea. Bull Eur Assoc Fish Pathol 9:9-11

Buchmann K (2007) An introduction to fish parasitological methods - classical and molecular techniques. Biofolia Press, Frederiksberg

*Bush AO, Lafferty KD, Lotz JM, Shostak AW (1997) Parasitology meets ecology on its own terms: Margolis et al. revisited. J Parasitol 83:575-583

Chubb JC, Pool DW, Veltkamp CJ (1987) A key to the species of cestodes (tapeworms) parasitic in British and Irish freshwater fishes. J Fish Biol 31:517-543

Dogiel V, Petruschevski G (1934) Die Wirkung des Aufenhaltsorts auf die Parasitenfauna des Lachses während seiner verschiedenen Lebensperioden. Arch Hydrobiol 26:659-673

Fagerholm HP (1982) Parasites of fish in Finland. VI. Nematodes. Acta Acad Aboensis Ser B 40:5-128

Grabda J (1974) The dynamics of the nematode larvae Anisakis simplex (Rud.) invasion in the south-western Baltic herring (Clupea harengus L.). Acta Ichthyol Piscat $4: 3-21$

Grabda J (1976) The occurrence of anisakid nematode larvae in Baltic cod (Gadus morhua callarias L.) and the dynamics of their invasion. Acta Ichthyol Piscat 6:3-22

Hansson S, Karlsson L, Ikonen E, Christensen O and others (2001) Stomach analyses of Baltic salmon from 19591962 and 1994-1997: possible relations between diet and yolksac-fry mortality (M74). J Fish Biol 58:1730-1745

*Herlemann DPR, Labrenz $M$, Jürgens $K$, Bertilsson $S$, Waniek JJ, Andersson AF (2011) Transitions in bacterial communities along the $2000 \mathrm{~km}$ salinity gradient of the Baltic Sea. ISME J 5:1571-1579

*Hicks FJ, Threlfall W (1973) Metazoan parasites of salmonids and coregonids from coastal Labrador. J Fish Biol 5: 399-415

Kabata Z (1963) Parasites as biological tags. Int Comm Northwest Atl Fish Spec Publ 4:31-37

Karlsson L, Karlström Ö (1994) The Baltic salmon (Salmo salar L.): its history, present situation and future. Dana 10:61-85

Karlsson L, Ikonen E, Mitans A, Hansson S (1999) The diet of salmon (Salmo salar) in the Baltic Sea and connections with the M74 syndrome. Ambio 28:37-42

Kennedy CR (1969) The occurrence of Eubothrium crassum (Cestoda: Pseudophyllidea) in salmon Salmo salar and trout $S$. trutta of the river Exe. J Zool 157:1-9

Kennedy CR (1978) Studies on the biology of Eubothrium salvelini and E. crassum in resident and migratory Salvelinus alpinus and Salmo trutta and in $S$. salar in North Norway and the islands of Spitsbergen and Jan Mayen. J Fish Biol 12:147-162

Køie M (1984) Digenetic trematodes from Gadus morhua L. (Osteichthyes, Gadidae) from Danish and adjacent waters, with special reference to their life-histories. Ophelia 23:195-222

K Køie M (1990) On the morphology and life-history of Hemiurus luehei Odhner, 1905 (Digenea: Hemiuridae). J Helminthol 64:193-202

Køie M (1992) Life cycle and structure of the fish digenean Brachyphallus crenatus (Hemiuridae). J Parasitol 78: 338-343 
Køie M (1993) Aspects of life cycle and morphology of Hysterothylacium aduncum (Rudolphi, 1802) (Nematoda, Ascaridoidea, Anisakidae). Can J Zool 71:1289-1296

Køie M, Kristiansen A, Weitemeyer S (2000) Animals and plants of the sea. Gads Publishers, Copenhagen (in Danish)

Kralova I, Hanzelova V, Scholz T, Gerdeaux D, Spakulova M (2001) A comparison of the internal transcribed spacer of the ribosomal DNA for Eubothrium crassum and Eubothrium salvelini (Cestoda: Pseudophyllidea), parasites of salmonid fish. Int J Parasitol 31:93-96

Larsson PO (1984) Growth of Baltic salmon Salmo salar in the sea. Mar Ecol Prog Ser 17:215-226

MacKenzie K (2002) Parasites as biological tags in population studies of marine organisms: an update. Parasitology 124:153-163

Margolis L (1965) Parasites as an auxiliary source of information about the biology of Pacific salmons (genus Oncorhynchus). J Fish Res Board Can 22:1387-1395

Margolis L, Arthur JR (1979) Synopsis of the parasites in fishes of Canada. Bull Fish Res Board Can 199:1-269

* Mehrdana F, Bahlool QZM, Skov J, Marana MH and others (2014) Occurrence of zoonotic nematodes Pseudoterranova decipiens, Contracaecum osculatum and Anisakis simplex in cod (Gadus morhua) from the Baltic Sea. Vet Parasitol 205:581-587

* Murphy TM, Berzano M, O'Keeffe SM, Cotter DM and others (2010) Anisakid larvae in Atlantic salmon (Salmo salar L.) grilse and post-smolts: molecular identification and histopathology. J Parasitol 96:77-82

Olsen MM, Heinecke RD, Skjødt K, Rasmussen KJ, Kania P, Buchmann K (2011) Cellular and humoral factors involved in the response of rainbow trout gills to Ichthyophthirius multifiliis infections: molecular and immunohistochemical studies. Fish Shellfish Immunol 30: 859-869

Pippy JHC (1980) The value of parasites as biological tags in Atlantic salmon at West Greenland. Rapp P-V Réun Cons Int Explor Mer 176:76-81

Reimchen TE (1982) Incidence and intensity of Cyathocephalus truncatus and Schistocephalus solidus infection in Gasterosteus aculeatus. Can J Zool 60:1091-1095

Reimer LW (1970) Digene Trematoden und Cestoden der Ostseefische als natürliche Fischmarken. Parasitol Schriftenr 20:1-143

Rosen F (1918) Recherches sur le développement des cestodes. I. Le cycle évolutif des Bothriocéphales. Bull Soc Neuchâtel Sci Nat 43:241-300

Saksvik M, Nylund A, Nilsen F, Hodneland K (2001) Experimental infection of Atlantic salmon (Salmo salar) with marine Eubothrium sp. (Cestoda: Pseudophyllidea): observations on the life cycle, aspects of development and

Editorial responsibility: Dieter Steinhagen,

Hannover, Germany growth of the parasite. Folia Parasitol 48:118-126

Scholz T, Kuchta R, Shinn AP, Snabel V, Hanzelova V (2003) Host specificity and geographical distribution of Eubothrium in European salmonid fish. J Helminthol 77 : 255-262

Slusarski W (1958) The adult digenea from salmonidae of the basin of Vistula and the South Baltic. Acta Parasitol Pol 6:247-482

* Sobecka E, Luczak E, Wiecaszek B, Antoszek A (2011) Parasite community structure of cod from Bear Island (Barents Sea) and Pomeranian Bay (Baltic Sea). Pol Polar Res 32:253-262

Sprehn CG, Blum MJ, Quinn TP, Heins DC (2014) Landscape genetics of Schistocephalus solidus parasites in threespine stickleback (Gasterosteus aculeatus) from Alaska. PLOS ONE 10:e0122307

Star B, Jentoft S (2012) Why does the immune system of cod lack MHCII? BioEssays 34:648-651

Timi JT (2003) Parasites of Argentine anchovy in the Southwest Atlantic: latitudinal patterns and their use for discrimination of host populations. J Fish Biol 63:90-107

Unger P, Palm HW (2016) Parasitation of sea trout (Salmo trutta trutta L.) from the spawning ground and German coastal waters off Mecklenburg-Western Pomerania, Baltic Sea. Parasitol Res 115:165-174

Valtonen ET, Gibson DI, Kurttila M (1984) Trematodes in Northern Finland I: species maturing in fish in the Northeastern Bothnian Bay and in a local lake. Bothnian Bay Rep 3:31-43

Verweyen L, Klimpel S, Palm HW (2011) Molecular phylogeny of the Acanthocephala (Class Palaeacanthocephala) with a paraphyletic assemblage of the orders Polymorphida and Echinorhynchida. PLOS ONE 6: e28285

Vik R (1963) Studies of the helminth fauna of Norway. IV. Occurrence and distribution of Eubothrium crassum (Bloch, 1779) and E. salvelini (Schrank, 1790) (Cestoda) in Norway, with notes on their life cycles. Nytt Mag Zool 11:47-73

Williams HH, MacKenzie K, McCarthy AM (1992) Parasites as biological indicators of the population biology, migrations, diet, and phylogenetics of fish. Rev Fish Biol Fish 2: $144-176$

Z Zhu XQ, Podolska M, Liu JS, Yu HQ and others (2007) Identification of anisakid nematodes with zoonotic potential from Europe and China by single-strand conformation polymorphism analysis of nuclear ribosomal DNA. Parasitol Res 101:1703-1707

*uo S, Kania PW, Mehrdana F, Marana MH, Buchmann K (2018) Contracaecum osculatum and other anisakid nematodes in grey seals and cod in the Baltic sea: molecular and ecological links. J Helminthol 92:81-89

Submitted: February 5, 2019; Accepted: June 19, 2019

Proofs received from author(s): August 23, 2019 